\title{
Interactive comment on "A unified code for conventional and disjunct eddy covariance analysis of trace gas measurements: An urban test case" by Marcus Striednig et al.
}

Marcus Striednig et al.

thomas.karl@uibk.ac.at

Received and published: 20 December 2019

We thank Reviewer 2 and Erik Velasco for their constructive comments. We have incorporated the suggestions and modified the paper accordingly. Our point by point reply and associated suggested changes are listed as outlined in the supplement of this reply.

Please also note the supplement to this comment:

https://www.atmos-meas-tech-discuss.net/amt-2019-272/amt-2019-272-AC2- 
Interactive comment on Atmos. Meas. Tech. Discuss., doi:10.5194/amt-2019-272, 2019.

Interactive comment 